\title{
DO JOB AUTONOMY AND NEGOTIATION SELF-EFFICACY IMPROVE EMPLOYMENT RELATIONSHIPS?
}

\author{
PETER R A OEIJ \\ peter.oeij@tno.nl \\ TNO Quality of life \\ Netherlands Organization for Applied Scientific Research \\ Hoofddorp (the Netherlands)
}

\begin{abstract}
This study investigated whether improving the employment relationship does more depend on negotiation selfefficacy or on task autonomy for a sample of employees from a Dutch telecom company. Multiple regression analyses were conducted to examine the effects of negotiation self-efficacy and task autonomy on integrative negotiation and the effect of integrative negotiation on psychological contract breach. Results indicate that employees negotiate more integratively when they have higher negotiation self-efficacy, compared to employees with more task autonomy. Empirical support was found for the prediction that higher negotiation self-efficacy and task autonomy correlates with less psychological contract breach.
\end{abstract}

Key words

Negotiation self-efficacy, task autonomy, psychological contract breach

Decentralisation and individualisation of employment relationships appear to become a trend in the Netherlands. It is observed that making agreements on the terms of employment are shifting from the level of collective bargaining to the level of the relationship between an employee and his or her direct supervisor (Huiskamp, 2004; Huiskamp, De Leede, \& Looise, 2002; Sparrow \& Cooper, 2003). This upcoming trend concerns for example agreements on working times, personal development and training, but less on matters such as wages and output standards (Oeij, Huiskamp, Goudswaard, Kwakkelstein, \& Nauta, 2005). It has become relevant to gain more insight into its consequences for the labour market position of employees. Is individual bargaining a better guarantee for solid terms of employment than collective bargaining? Does individual bargaining result in more individually different deals (Rousseau, 2005) and is that a problem from the viewpoint of social inequality? These social issues are to be seen as associated with a growing preference of employees for tailor-made employment conditions - specially related to greater flexibility and control over working hours - which is not limited to the Netherlands but is observed in many of the economically most developed member states of the European Community, like Germany, France, Italy and the UK (Bielensky, Bosch, \& Wagner, 2002; Delsen, Benders, \& Smits, 2006; Messenger, $2004)$. Not only employees favour individualised employment conditions. Employers recognize positive consequences for organisational performance as well, since this would make their organisations more flexible and cost-effective (Benders, Delsen, \& Smits, 2006). Along with decentralisation and individualisation of the employment relationship comes negotiating between employee and supervisor, since organisations offer choices within their collective labour agreements (Delsen et al., 2006). This may offer opportunities for good deals, but can also contain risks for making bad deals. How can risks of social inequality for employees be minimized at shop floor level? Should employees possess of special negotiation skills to prevent making bad deals? Or should jobs guarantee employees enough autonomy so they have a sense of sovereignty over their work? Such issues justify an exploration of relations and directions of associations within the employment relationship, especially of relations and their directions between negotiation, negotiation self-efficacy, job autonomy and psychological contract breach. The purpose of this article is to contribute to insight how one can improve employment relationships in the context of decentralisation and individualisation of bargaining on the terms of employment. Should employees become better negotiators or should high autonomy jobs be designed?

Individualisation of the employment relationship implies a growing importance of negotiation self-efficacy. Bandura, who is stating that self-efficacy demands are enhancing given the rapid pace of informational, social, and technological change, observes a similar situation in North America: "In the modern workplace, workers have to take charge of their selfdevelopment for a variety of positions and careers over the full course of their work life" (Bandura, 2001b, p. 11). Negotiation self-efficacy might be part of this improved employability. Negotiation self-efficacy is defined as regarding oneself capable to negotiate integratively. Integrative negotiation combines the capability of doing justice to one's own goals and to the goals of others as well (cf. Blake \& Mouton, 1984; De Dreu 1999). In the applied definition, therefore, negotiation self-efficacy combines the domain of successfully striving after one's own goals and to reach a good relation with the other party. Take note that negotiation is about behaviour, whereas negotiation self-efficacy deals with personal skills to negotiate. Perceived self-efficacy goes one step further and indicates how one judges oneself to actually perform his or her negotiation skills in a successful way under certain circumstances. According to Bandura perceived selfefficacy is 'concerned with people's beliefs in their capabilities to produce given attainments', or, 'to produce designated levels of performance that exercise influence over events that affect their lives' (Bandura, 1994; Bandura, 2001a). There is a wealth of research on self-efficacy related to a variety of domains (Bandura, 1997), but research on selfefficacy in relation to negotiation is relatively scarce (Gist, Stevens, \& Bavetta, 1991; O'Connor \& Arnold, 2001; O'Connor, Arnold, \& Burris, 2005; Stajkovic \& Luthans, 1998; Stevens \& Gist, 1997; Sullivan, O'Connor, \& Burris, 2003), and almost absent in combination with the employment relationship (Stevens, Bavetta, \& Gist, 1993). Research found in this regard was only carried out among student populations 
and not among employees. For this reason, the opportunity occurred to design a new domain specific measuring instrument for negotiation self-efficacy (Bandura, 2001a). Because personal skills are basic to negotiation selfefficacy (Bandura, 2001b) these skills can be a relevant condition for the resulted agreements in the employment relationship. Such results, however, do not necessarily stem from personal negotiation skills alone. Job design can also play an important role as a possible condition for the employment relationship, because the autonomy in jobs could render bargaining power.

Labour market theory suggests that people in jobs with high autonomy have a strong labour market position (Doeringer \& Piore, 1971; Loveridge \& Mok, 1979; OECD, 2005; Ouchi, 1980; Ten Have \& Vissers, 1987; Watson, 1995; Williamson, 1981). High job autonomy indicates higher educational training and higher income and an absence of the need to reach worker productivity by management control strategies - contrary to so called commitment strategies (Watson, 1995). Employees with high job autonomy may, therefore, have better opportunities to reach satisfying negotiation agreements because they have power. Firstly, because employers may depend on workers with high qualifications, especially in knowledge oriented industrial sectors (Batenburg, Asselberghs, Huijgen, \& Van der Meer, 2003). Secondly, autonomy gives employees a certain amount of freedom how to perform tasks and when, in which order they execute tasks and how fast. Job autonomy is the job decision latitude or job discretion (Karasek \& Theorell, 1990) with reference to skill variety and allocated autonomy (Ouwerkerk, Meijman, \& Mulder, 1994). High autonomy indicates that the person on the job is a critical resource to the employer (Van Dijck, 1989). High autonomy jobs are complex jobs with a limited division of labour (De Sitter, Den Hertog, \& Dankbaar, 1997). Organisations offering such jobs, therefore, are inclined to ensure productivity through 'commitment' instead of 'control'. In other words, professional autonomy versus management autonomy (Fruytier, 1998; Walton \& Hackman, 1986). Because job design is the basis for job autonomy we regard it also a condition for the arrived agreements in the employment relationship. Job autonomy implies power to successfully bargain over favourable terms of employment.

The question thus arises if better employment relationships can be arrived at through enhancing (personal) negotiation skills, or (organisational) job design, or both. Therefore, a first step is to research whether job autonomy or negotiation self-efficacy has the strongest effect on negotiation behaviour. Next, effects of job autonomy and negotiation self-efficacy on psychological contract breach will be examined to explore the relation with the satisfaction with agreements within the employment relationship, i.e. negotiation results. Positive evaluations of psychological contract breach are regarded as an indicator of satisfaction with the employment relationship.

Following an often cited definition by Pruitt, negotiation in the context of the employment relationship - with regard to working time, leave, development and training, wages and output - can be regarded as a decision making process in which parties may try to bridge opposed interests by means of communication (Pruitt, 1981; Pruitt \& Carnavale, 1993). Looking for compromises and solutions that benefit both parties (win-win) is integrative negotiation, while the opposite, striving after one's self interest (win-lose) is distributive negotiation (Beersma \& De Dreu, 2002; De Dreu, 1999; Pruitt \& Carnavale, 1993). It is likely that integrative negotiation occurs with high job autonomy and high negotiation selfefficacy. High autonomy with a strong labour market position will make distributive negotiation redundant. Employers will treat these employees well by investing in these human resources with good terms of employment. To replace such workers is expensive due to losing returns on investment in training and recruitment costs. Therefore, employees like these will not often have to exert power. For being provided with relatively much autonomy, employees are expected to propagate the company's rules to other workers in return. As a matter of speech one could state that high autonomy jobs are in a way designed to prevent costly conflicts (cf. Baron \& Kreps, 1999, pp. 62-86, pp. 326-332; Mangolte, 2000; Williamson, 1981). High negotiation self-efficacy, with the intention to also take care of others' interests, will result in a preference for an integrative style. It is assumed that such employees are very likely to avoid a distributive negotiation style, because they are not selfish.

It is suggested that both high job autonomy and high negotiation self-efficacy positively effect integrative negotiation. Hence:

Hypothesis 1a: Among high job autonomy employees, more integrative negotiation will be performed, compared to low job autonomy employees.

Hypothesis 1b: Among high negotiation self-efficacy employees, more integrative negotiation will be performed, compared to low negotiation self-efficacy employees.

Job autonomy and negotiation self-efficacy differ in the sense that the first is a job characteristic and the second a behavioural characteristic, or, in other words, situational and personal respectively (Bandura, 1986; Bandura, 1997). Since it is assumed that the coherence between behavioural characteristics and behaviour is stronger than between job characteristics and behaviour (cf. Adler, 1996; Fiske, 2004), a stronger correlation is expected between negotiation self-efficacy and integrative negotiation than between job autonomy and integrative negotiation. In other words, the main effect of negotiation selfefficacy will be larger than the main effect of job autonomy. Therefore:

Hypothesis 1c: the correlation between negotiation self-efficacy and integrative negotiation is stronger than the correlation between job autonomy and integrative negotiation.

Integrative negotiating styles may help in avoiding psychological contract breach in reaching agreements in the employment relationship (Robinson, 1996; Rousseau, 2004; Rousseau, 2005). Psychological contract breach is an indicator for satisfaction with the negotiated results, i.e. employment relationship satisfaction. Evaluations on psychological contract breach are defined as the degree to which employees feel that the employer fulfills expectations and promises made about the job. Several studies suggest high levels of job autonomy stemming from a high quality of work shows a relationship with high levels of job satisfaction (Hackman \& Oldham, 1975; Karasek \& Theorell, 1990; Loher, Noe, Moeller, \& Fitzgerald, 1985; Van Der Parre, 1996). Therefore, it is assumed that high job autonomy employees, compared to those with low job autonomy, will experience less psychological contract breach. Bandura's social-cognitive theory $(1986,1997)$ predicts a contribution of high self-efficacy to effective behaviour resulting in higher satisfaction with the outcomes of such behaviour. Applied to employment relationships this would imply that high self-efficacy employees would realise better negotiation outcomes. Consequently, this will result in the absence of psychological contract breach. From these statements on job characteristics (job autonomy) and behavioural characteristics (negotiation self-efficacy) follow the next hypotheses:

Hypothesis 2a: High job autonomy employees evaluate psychological contract breach to a more positive degree compared to low job autonomy employees. 
Hypothesis 2b: High negotiation self-efficacy employees evaluate psychological contract breach to a more positive degree compared to low negotiation self-efficacy employees.

Employees as distributive negotiators might be less satisfied with their employment relationship, compared to integrative negotiators. Therefore, we will investigate the relation between integrative negotiation with evaluations of psychological contract breach. Consequently:

Hypothesis 2c: High integratively negotiating employees have positive evaluations of psychological contract breach to a higher degree compared to low integrative negotiating employees.

\section{RESEARCH DESIGN}

Research approach

Cross-sectional survey data were used among a sample of randomly selected employees from a Dutch telecom company. Participants were approached through the intranet system of the company.

\section{Research methodology \\ Research participants}

Among a total of 294 participants questionnaires were distributed via electronic mail, of which 136 completed questionnaires were returned via electronic mail, a response rate of $46,3 \%$. Sample characteristics are $73 \%$ men and $27 \%$ women. Average age is 41,2 years (SD: 8.18 , range 27-58 years). Average length of employment is 9,3 years (SD: 8.30, range 1-39 years). The average weekly working hours is 35,9 (SD: 5.65 ), $81,8 \%$ works full time (36 hours or more weekly). The distribution of educational level is $2,9 \%$ lower vocational, $52,2 \%$ middle vocational, $30,9 \%$ higher vocational and $11,8 \%$ university degree; $2,2 \%$ has an education of a different kind.

\section{Measuring instruments}

Negotiation behaviour. The DUtch Test of Conflict Handling (DUTCH) (De Dreu, Evers, Beersma, Kluser \& Nauta, 2001) was used to assess negotiation behaviour, which comprises five styles, 'yielding', 'problem solving', 'avoiding', 'forcing', and 'compromising' (15 items, 3 items per style, five point scale). By factor analysis the DUTCH was reduced into two dimensions, 'integrative negotiation' and 'distributive negotiation', of which only the first dimension was used in further analyses which we labelled 'negotiation behaviour' (Cronbach's $\alpha$ 0,81). High scores are interpreted as integrative negotiation and low scores as non-integrative negotiation. Negotiation behaviour was measured using critical incidents, namely, whether a person experienced a problem or dissatisfaction in the employment relationship that urged the employee or the supervisor to modify the employment relationship in terms of working times, leave, wage, training opportunities, and output. Respondents were first asked if they experienced such a problem during the last two years. If so, the next question asked was if the employee could remember discussing this problem with his or her direct supervisor. For more than a third (36\%) of the respondents who experienced such problems we could examine their negotiation style.

Lob autonomy. We measured job autonomy with the scale 'autonomy' ( 5 items, five point scale) taken from the validated NOVA WEBA questionnaire (Dhondt \& Houtman, 1992; Kraan, Dhondt, Houtman, Nelemans, \& De Vroome, 2000). NOVA WEBA is built on the Job Content Questionnaire (Karasek \& Theorell, 1990), and the concept of 'control capacity' from modern sociotechnology (De Sitter et al., 1997). Cronbach's $\alpha$ was 0,86 .
Negotiation self-efficacy. Based on Bandura's (2001a) guide for constructing self-efficacy scales the newly developed five point scale integrates two dimensions (Oeij, 2006). Three items concern 'successfully pursuing one's goals' ("I am confident to reach the negotiation goal I have set in advance", "I will succeed to push through the changes that I wish", "I am well capable to defend my own interests") and three items refer to "bring about a good relationship with the direct supervisor" "I will succeed in creating a pleasant atmosphere during the assessment interview", "I am capable of winning my direct supervisor over to my cause", "I am capable of convincing my direct supervisor about my worth for the job"). High scores mean that the respondent perceives himself as being capable to simultaneously looking after his own interests and a good relationship with the direct supervisor, which enables him to perform integrative negotiation. Cronbach's $\alpha$ was 0,84 .

Psychological contract breach. Psychological contract breach was measured by the degree to which employees feel that their employer fulfils expectations and promises made during the application or an earlier assessment interview. For this purpose we adapted questions developed by Robinson (1996) and Robinson and Morrison (2000) into a six item five point scale. High scores show the experience of psychological contract breach. Cronbach's $\alpha$ was 0,67 .

\section{Research procedure}

Questionnaires were distributed via electronic mail and responses were also returned via electronic mail.

\section{RESULTS}

Table 1 shows that job autonomy does not significantly correlate with integrative negotiation. Besides, the correlation points to another direction than we expected. Negotiation self-efficacy significantly correlates strongly with integrative negotiation $(\mathrm{r}=$ $0,43, p<0,01)$, moderately with job autonomy $(r=0,35, p<$ $0,01)$, and approximately moderately with psychological contract breach $(r=-0,28, p<0,01)$. There is, however, no relation between integrative negotiation and psychological contract breach. The number of observations for the construct integrative negotiation is 49 . As explained in the previous Section, this is a consequence of routing, not of non-response. The percentage of the response on this construct is $36 \%$, referring to respondents who had experienced discontent with the employment relationship, resulting in a wish to change agreements. These respondents were engaged in actually negotiating their employment relationship. This percentage corresponds with findings from another research among 4.240 employees in which $38 \%$ of respondents confirmed that they had experienced an imbalance, meaning that their work or work situation no longer fitted with the respondent's wishes (Nauta \& Van Sloten, 2004 ). Although the percentage of $36 \%$ of the employees who experienced discontent is substantial, the absolute number of cases constrained the number of variables to be entered in the multiple regression analyses. As a consequence, these multivariate analyses lead to findings that are restricted to respondents who negotiated their employment relationship.

TABle 1

DESCRIPTIVE STATISTICS (MEANS, STANDARD DEVIATIONS AND CORRELATIONS) $\mathbf{N}$ MAXIMUM $=136$

\begin{tabular}{lcccccc}
\hline Variable & N & M & SD & 1 & 2 & 3 \\
\hline Job autonomy & 136 & 3,79 & 0,67 & & & \\
Negotiation self-efficacy & 135 & 3,53 & 0,60 & $0,35 * *$ & & \\
Integrative negotiation & 49 & 3,13 & 0,84 & $-0,13$ & $0,43 * *$ & \\
Psychological contract breach & 136 & 2,35 & 0,62 & $-0,37^{* *}$ & $-0,28^{* *}$ & .01
\end{tabular}

${ }^{* *} \mathrm{p}<.01$ (two-sided) 
For the most complete presentation of results in Table 2, we both use the unstandardised partial regression coefficient (B) to show the absolute effect of the concerned independent variable on the dependent variable, held constant for the influence of other independent variables - as well as the standardised regression coefficients (beta) - which compute the relative importance of each independent variable in explaining the dependent variable. It cannot be corroborated that high autonomy employees perform more integrative negotiation than low autonomy employees (hypothesis $1 \mathrm{a}$ ), as model 1 does not show a significant partial coefficient of correlation $(\mathrm{B}=$ 0,30 ). The direction of the correlation is opposite to our expectation: more job autonomy stimulates non-integrative negotiation. Contrary to our expectations a power position may result in a forcing negotiation style. However, results confirm that high negotiation self-efficacy employees perform more integrative negotiation $(B=0,74, p<0,01$ ) (hypothesis $1 b$ ). Finally, negotiation self-efficacy appears to correlate more strongly with integrative negotiation than job autonomy (Table 1 ), which is an indication for the support of hypothesis 1c. Although job autonomy and negotiation self-efficacy correlate moderately $(\mathrm{r}=0,35, \mathrm{p}<0,01)$, we did not find a significant interaction effect (using the procedure of Aiken \& West, 1991), for example that among low job autonomy employees the effect of high negotiation self-efficacy on integrative negotiation would be larger than by high autonomy employees. Results indicate that both low and high autonomy employees perform more integrative negotiation as they have higher negotiation self-efficacy.

Finally, we investigated how job autonomy, negotiation self-efficacy and integrative negotiation related to evaluations of psychological contract breach (hypotheses 2a, b, and c). Model 2 (Table 2) shows that possessing job autonomy is a predictor for psychological contract breach to remain absent $(B=-0,36, p<0,05)$. Remarkably, negotiation selfefficacy and integrative negotiation do not predict psychological contract breach.

The results of the multiple regression analyses are necessarily restricted, however, to only those respondents who actually had negotiated their own employment relationship with their supervisor in the previous two years $(\mathrm{N}=49)$. Significant results in this respect can therefore only be generalized to employees who experience such negotiations in practice.

\section{TABLE 2}

MULTIPLE REGRESSION WITH INTEGRATIVE NEGOTIATION AND PSYCHOLOGICAL CONTRACT BREACH AS DEPENDENT VARIABLES

\begin{tabular}{|c|c|c|c|c|}
\hline & \multicolumn{2}{|c|}{$\begin{array}{l}\text { Integrative } \\
\text { negotiation }\end{array}$} & \multicolumn{2}{|c|}{$\begin{array}{l}\text { Psychological } \\
\text { contract breach }\end{array}$} \\
\hline & B & $\beta$ & B & $\beta$ \\
\hline \multicolumn{5}{|l|}{ Model 1} \\
\hline Job autonomy & $-0,30$ & $-0,24$ & & \\
\hline Negotiation self-efficacy & $-0,74$ * * & 0,49 ** & & \\
\hline Constant & $1,68 *$ & & & \\
\hline $\mathrm{R}^{2}$ & 0,24 & & & \\
\hline $\mathrm{F}(2,48)$ & $7,32 * *$ & & & \\
\hline $\mathrm{N}$ & 49 & & & \\
\hline \multicolumn{5}{|l|}{ Model 2} \\
\hline Job autonomy & & & $-0,36^{*}$ & $-0,35$ * \\
\hline Negotiation self-efficacy & & & $-0,19$ & $-0,15$ \\
\hline Integrative negotiation & & & 0,02 & 0,03 \\
\hline Constant & & & 4,38 ** & \\
\hline $\mathrm{R}^{2}$ & & & 0,17 & \\
\hline $\mathrm{F}(3,48)$ & & & $3,10^{*}$ & \\
\hline $\mathrm{N}$ & & & 49 & \\
\hline
\end{tabular}

${ }^{*} \mathrm{p}<0,05,{ }^{* *} \mathrm{p}<0,01$
The hypothesis (1a) that employees with high job autonomy will negotiate more integratively was not supported. Some evidence, however, was found for the hypothesis (1b) that high negotiation self-efficacy contributes to integrative negotiation behaviour, indicating that personal characteristics have a stronger effect on integrative negotiation than situational characteristics. Findings on the relation between negotiation self-efficacy and integrative negotiation support this argumentation, because the bivariate correlation between these variables is stronger than the correlation between job autonomy and integrative negotiation (hypothesis 1c). Job autonomy appears to be positively related to the absence of psychological contract breach (hypothesis 2a), whereas negotiation self-efficacy is not related to experiencing lower psychological contract breach (hypothesis $2 \mathrm{~b}$ ). Finally, no support was found for the hypothesis (2c) that integrative negotiation was related to positive judgements of psychological contract breach.

\section{DISCUSSION}

The present study suggests that negotiation self-efficacy supports integrative negotiation behaviour and, at least bivariately, positive evaluations of negotiated results in the employment relationship, for which psychological contract breach is used as an indicator. Contrary to this finding, job autonomy is no guarantee for integrative negotiation. Job autonomy does, however, contribute to not experiencing psychological contract breach. Given the positive relation between job autonomy and negotiation self-efficacy, it is plausible that high job autonomy enhances a person's bargaining position or that good negotiation skills create job autonomy. In the first case, more negotiation self-efficacy might lead to integrative negotiation and positive evaluations of negotiation outcomes. Some studies support that high selfefficacy improves effective negotiation behaviour (Gist et al., 1991; O'Connor et al., 2005; Stevens et al., 1993; Stevens \& Gist, 1997; Sullivan et al., 2003), but studies on the relation between self-efficacy employment relations are rare and not unequivocal. Stevens et al. (1993) found that respondents who had followed self-management training on negotiation tactics enhanced their negotiation skills. However, among other variables such as perceived control and goal setting, self-efficacy had no clear effects on negotiating larger salaries. In a replication of the study from Gist et al. (1991), Stevens and Gist (1997) examined the effects of self-efficacy on negotiation skill maintenance of trainees. High self-efficacy trainees performed better than low self-efficacy trainees but not in all conditions. In the second case, more job autonomy might result in distributive negotiation behaviour without experiencing psychological contract breach. The relationship among these variables, however, is more complex than presented here, as can for example be read in the research of Sullivan et al. (2003), who are stating that an individual's self-efficacy affects the choice of tactics, which affects whether individuals will negotiate integratively or distributively. The findings of these and the present research lead to the suggestion that more mediating studies are necessary to single out the relations between selfefficacy, job content and negotiation in employment relationships. Particularly, given that negotiation is a dyadic, interdependent task.

Is it plausible to interpret the findings as two separate roads to employment relationship satisfaction, either through enhancing negotiation skills of individuals or by improving autonomy in jobs? A tentative answer would be positive, since job autonomy and negotiation self-efficacy both lead to a positive correlation with the indicator of satisfaction with the employment relationship, namely less psychological contract breach. Nonetheless, thorough insight into the relations between negotiation skills, well-designed jobs and harmonious employment relationships is necessary to allow for such a conclusion. Further research is suggested in at least two 
directions. First, it would help to relate negotiation behaviour to concepts of personality to investigate how differences in negotiation styles are explained (Barrick \& Mount, 1991). Does one style or another enable integrative negotiation behaviour? Second, it is relevant to take into account situational variables such as the labour market situation in different industrial sectors for various professions. Generally speaking, a shrinking economy puts bargaining power into the hands of management, and an expanding economy into those of employees, which affects job satisfaction (Gallie, White, Cheng \& Tomlinson, 1998). How does someone's labour market position affect negotiation behaviour? Such extensions of the theoretical research framework would help to avoid the shortcoming of entering only a limited number of variables in the analyses in the present study, namely one aspect of individual behaviour (self-efficacy) and one aspect of job design (autonomy), whereas research on interdependent negotiation would justify more controlling variables.

A few limitations of the findings should be mentioned. Firstly, based on the present research no causal inferences can be made on the basis of the cross-sectional data. Secondly, in using self-report questionnaires biases in the respondents' evaluations cannot be excluded. A third limitation may be that the data were collected in a single organisation, which does not allow generalisation to, for example, professions and sector, implying that findings should be ascribed to particular characteristics of this organisation. Arguments against these limitations are that theoretical insights were tested with no ambition for making sweeping statements that ought to be representative for larger populations of any kind. Finally, larger datasets are necessary to confirm the relations found in this explorative study.

The scientific relevance of this study is more insight in how employees negotiate in the employment relationship. It seems that behavioural characteristics, like negotiation self-efficacy, have a strong positive effect on integrative negotiations. The findings underline Bandura's statement (2001b) on the importance of personal efficacy in reaching success, here applied to employment relations. An important contribution of this research, therefore, is the newly developed measuring scale for negotiation self-efficacy, which proves to be reliable i.e. internally valid.

\section{ACKNOWLEDGEMENTS}

I thank Anneke Goudswaard, Karolus Kraan, Aukje Nauta, Ernest de Vroome (TNO), Matthee Reijnders and Peter Verboon (Open University Netherlands) and two anonymous reviewers for their helpful comments.

This is a revised version of a paper presented at the XVI ISA World Congress of Sociology in Durban, 23-29 July, 2006 under the title "How Employees Negotiate: Task Autonomy and SelfEfficacy Related to Integrative Negotiation and Negotiation Results in Employment Relationships".

Address correspondence to Peter R.A. Oeij, TNO Quality of life, P.O. Box 718, 2130 AS Hoofddorp, The Netherlands. Email: peter.oeij@tno.nl

\section{REFERENCES}

Adler, S. (1996). Personality and Work Behaviour: Exploring the Linkages. Applied Psychology, 45 (3), 207-224.

Aiken, L. S. \& West, S. G. (1991). Multiple Regression: Testing and Interpreting Interactions. Newbury Park, CA: Sage Publications.

Bandura, A. (1986). Social Foundations of Thought and Action: A Social Cognitive Theory. Englewood Cliffs, N.J.: Prentice-Hall.
Bandura, A. (1994). Self-Efficacy. In V. S. Ramachaudran (Ed.), Encyclopedia of Human Behavior (Vol. 4, pp. 71-81). New York: Academic Press.

Bandura, A. (1997). Self-Efficacy: The Exercise of Control. New York: Freeman.

Bandura, A. (2001a). Guide for constructing Self-Efficacy Scales (Revised), from Frank Pajares, Emory University; Albert Bandura, Stanford University (http://www.emory.edu).

Bandura, A. (2001b). Social Cognitive Theory: An Agentic Perspective. Annual Review of Psychology, 52, 1-26.

Baron, J. N. \& Kreps, D. M. (1999). Strategic Human Resources: Frameworks for General Managers. New York, etc.: John Wiley \& Sons.

Barrick, M.R. \& Mount, M.K. (1991). The Big Five Personality Dimensions and Job Performance: A Meta Analysis. Personnel Psychology, 44 (1), 1-26.

Batenburg, R., Asselberghs, K., Huijgen, F. \& Van der Meer, P. (2003). De kwalitatieve structuur van de werkgelegenheid in Nederland Deel V. Trends en verschillen in de werkgelegenheid naar beroepsniveau in de periode 1987-2000. Den Haag: Servicecentrum Uitgevers.

Beersma, B., \& De Dreu, C. K. W. (2002). Integrative and Distributive Negotiation in Small Groups: Effects of Task Structure, Decision Rule and Social Motive. Organizational Behavior and Human Decision Processes, 87 (2), 227-252.

Benders, J., Delsen, L. \& Smits, J. (forthcoming 2006). Bikes Versus Lease Cars: The Adoption, Design and Use of Cafetaria Systems in the Netherlands. International Journal of Human Resources Management, 17.

Bielenski, H., Bosch, G. \& Wagner, A. (2002). Working Time Preferences in Sixteen European Countries. Luxembourg: Office for Official Publications of the European Communities.

Blake, D. R. S. \& Mouton, J. S. (1984). Solving Costly Organizational Conflicts: Achieving Intergroup Trust, Cooperation, and Teamwork. San Francisco, CA: Jossey-Bass.

Cohen, J. (1969 [1e], 1988 [2e]). Statistical Power Analysis for the Behavioral Sciences. Revised Edition. Hilsdale, New Jersey: Lawrence Erlbaum Associates.

De Dreu, C. K. W. (1999). Conflicten in organisaties: Wat hebben we eraan en wat moeten we ermee? Gedrag en Organisatie, 12 (4), 189-204.

De Dreu, C. K. W., Evers, A., Beersma, B., Kluwer, E. S. \& Nauta, A. (2001). A Theory-based Measure of Conflict Management Strategies in the Workplace. Journal of Organizational Behavior, 22, 645-668.

Delsen, L., Benders, J. \& Smits, J. (2006). Choices Within Collective Labour Agreements à la Carte in the Netherlands. British Journal of Industrial Relations, 44 (1), 51-72.

De Sitter, L. U., Den Hertog, J. F. \& Dankbaar, B. (1997). From complex organizations with simple jobs to simple organisations with complex jobs. Human Relations, 50 (5), 497-534.

Dhondt, S. \& Houtman, I. (1992). NIPG Onderzoeksvragenlijst arbeidsinhoud: Constructie en eerste test op betrouwbaarheid en validiteit. Leiden: NIPG-TNO.

Doeringer, P. \& Piore, M. (1971). Internal labour markets and manpower analysis. Lexington, Mass.: D.C. Health.

Fiske, S.T. (2004). Social Beings: A Core Motives Approach to Social Psychology. Hoboken, NJ: Wiley \& Sons.

Fruytier, B. (1998). Werknemersmacht in de arbeidsorganisatie: Voorwaarde voor het poldermodel: Flexibilisering, individualisering en het systeem van collectieve arbeidsverhoudingen in Nederland. Den Haag: Servicecentrum Uitgevers.

Gallie, D., White, M., Cheng, Y., \& Tomlinson, M. (1998). Restructuring the Employment Relationship. Oxford: Clarendon Press.

Gist, M. E., Stevens, C. K., \& Bavetta, A. G. (1991). Effects of SelfEfficacy and Post-Training Intervention on the Acquisition and Maintenance of Complex Interpersonal Skills. Personnel Psychology, 44 (5), 837-861. 
Hackman, J. R. \& Oldham, G. R. (1975). Development of the Job Diagnostic Survey. Journal of Applied Psychology, 60 (2), 159170.

Huiskamp, R. (2004). Employment relations in transition: An introduction in theory, trends and practice. Utrecht: Lemma.

Huiskamp, R., De Leede, J. \& Looise, J. C. (2002). Arbeidsrelaties op maat: naar een derde contract? Assen: Koninklijke Van Gorcum.

Karasek, R. A. \& Theorell, T. G. T. (1990). Healthy Work: Stress, Productivity and the Reconstruction of Working Life. New York: Basic Books.

Kraan, K., Dhondt, S., Houtman, I., Nelemans, R. \& De Vroome, E. (2000). Handleiding NOVA-WEBA. Een vragenlijst om arbeidsorganisatorische knelpunten op te sporen. Hernieuwde versie. Hoofddorp: TNO Arbeid.

Loher, B. T., Noe, R. A., Moeller, N. L. \& Fitzgerald, M. P. (1985). A Meta-Analysis of the Relation of Job Characteristics to Job Satisfaction. Journal of Applied Psychology, 70, 280-289.

Loveridge, R. \& Mok, A.L. (1979). Theories of Labour Market Segmentation: A Critique. The Hague, Boston, London.

Mangolte, P. A. (2000). Organisational Learning and the Organisational Link: The problem of Conflict, Political Equilibrium and Truce. European Journal of Economic and Social Systems, 14 (2), 73-190.

Messenger, J. C. (Ed.) (2004). Working Time and Workers' Preferences in Industrialized Countries: Finding the Balance. London: Routledge.

Nauta, A. \& Van Sloten, G.C. (2004). De dialoog als vroege poortwachter: Het voorkomen van verzuim door onbalans. Assen: SMS/Van Gorcum.

O'Connor, K. M. \& Arnold, J. A. (2001). Distributive Spirals: Negotiation Impasses and Moderating Effects of disputant Self-Efficacy. Organizational Behavior and Human Decision Processes, 84, 148-176.

O'Connor, K. M., Arnold, J. A. \& Burris, E. R. (2005). Negotiator's Bargaining Histories and their Effects on future Negotiation Performance. Journal of Applied Psychology, 90 (2), 350-362.

Oeij, P.R.A. (2006). Bevorderen onderhandelingsvaardigheden en taakautonomie goede arbeidsrelaties? Tijdschrift voor Arbeidsvraagstukken, 22 (1), 55-67.

Oeij, P., Huiskamp, R., Goudswaard, A., Kwakkelstein, K. \& Nauta, A. (2005). Samen afspraken maken over arbeidsrelaties: Mythe of werkelijkheid? M\&O Tijdschrift voor Management en Organisatie, 59 (1), 25-40.

Organisation for Economic Co-operation and Development (2005). OECD Employment Outlook 2005. Paris: OECD.

Ouchi, W.G. (1980). Markets, Bureaucracies, and Clans. Administrative Science Quarterly, 22, 541-544.

Ouwerkerk, R. J., Meijman, T. F. \& Mulder, G. (1994). Arbeidspsychologische taakanalyse: Het onderzoek van cognitieve en emotionele aspecten van arbeidstaken. Utrecht: Lemma.
Pruitt, D. G. (1981). Negotiation Behavior. New York: Academic Press.

Pruitt, D. G. \& Carnevale, P. C. (1993). Negotiation in Social Conflict. Pacific Grove, CA: Brooks/Cole.

Robinson, S. L. (1996). Trust and Breach of the Psychological Contract. Administrative Science Quarterly, 41, 574-599.

Robinson, S. R. \& Morrison, E. W. (2000). The Development of Psychological Contract Breach and Violation: A Longitudinal Study. Journal of Organizational Behavior, 21, 525-546.

Rousseau, D. M. (2004). Psychological Contracts in the Workplace: Understanding the Ties that Motivate. Academy of Management Executive, 19 (1), 120-127.

Rousseau, D. M. (2005). I-deals: Idiosyncratic Deals Employees Bargain for Themselves. New York, London: Sharpe.

Sparrow, P.R. \& Cooper, C.L. (2003). The Employment Relationship: Key Challenges for HR. Amsterdam, etc.: Butterworth-Heinemann.

Stajkovic, A. D. \& Luthans, F. (1998). Self-Efficacy and workrelated Performance: A Meta-Analysis. Psychological Bulletin, $124,240-261$.

Stevens, C. K., Bavetta, A. G. \& Gist, M. E. (1993). Gender Differences in the Acquisition of Salary Negotiation Skills: The Role of Goals, Self-Efficacy, and Perceived Control. Journal of Applied Psychology, 78 (5), 723-735.

Stevens, C. K. \& Gist, M. E. (1997). Effects of Self-Efficacy and Goal-Orientation Training on Negotiation Skills Maintenance: What are the Mechanisms? Personnel Psychology, 50, 955-978.

Sullivan, B. A., O'Connor, K. M. \& Burris, E. (2003). Negotiator Confidence: The Impact of Self-Efficacy on Tactics and Outcomes, from Academy of Management: http://ssrn. com/abstract $=404584$

Ten Have, K. \& Vissers, A. (1987). Arbeid tussen markt en organisatie. The Hague: OSA.

Van Der Parre, P. (1996), Zonder arbeid geen zegen: Kwaliteit van de arbeid, arbeidsorientaties, arbeidssatisfactie en het zoekgedrag op de arbeidsmarkt. Diss. EUR. Delft: Eburon.

Van Dijck, J. J. J. (1989). Naar een personeelmanagement 'nieuwe stijl'. In J. J. J. Van Dijck (red.), Ondernemen met mensen. Strategische keuzen rond 'human resources' (pp. 15-19). Deventer: Kluwer Bedrijfswetenschappen.

Walton, R. E. \& Hackman, J. R. (1986). Groups Under Contrasting Management Strategies. In P.S. Goodman (Ed.), Designing Effective Work Groups (pp. 72-119). San Francisco, CA: Jossey-Bass Publishers.

Watson, T. J. (1980 [1e], 1995 [3e]). Sociology, Work and Industry. London: Routledge \& Kegan Paul.

Williamson, O.E. (1981). The Economics of Organization: The Transaction Cost Approach. American Journal of Sociology, 3, 548-577. 